УдК 349.2

DOI https://doi.org/10.32837/pyuv.v1i3(28).341

B. B. Китайгородська аспірант кафедри цивільно-правових дисииплін і трудового права імені професора О. І. Процевського Харківського національного педагогічного університету імені Г.С.Сковороди

\title{
ПОНЯТТЯ ТА ЗМІСТ ПРАВА ЛЮДИНИ НА ПРАЦЮ
}

Для нормальної життєдіяльності людини необхідно мати можливість забезпечити себе та членів своєї сім'ї певними матеріальними і нематеріальними благами - житлом (будинком або квартирою), одягом, продуктами харчування тощо. Спочатку людина забезпечувала себе самостійно (ходила на полювання, пасла приручену худобу, шила собі зі шкіри одяг, збирала плоди). У процесі діяльності людина почала придумувати інструменти, з якими вона освоювала, змінювала і адаптувала до своїх потреб об’єкти, що оточували їі.

3 набуттям певного досвіду і знань у своєму житті вона поліпшила свої навички і покращила інструменти, все частіше почала використовувати фізичні, механічні та хімічні властивості оточуючих предметів і природних явищ для задоволення зростаючих потреб.

Іншими словами, щоб вижити, необхідно працювати. Це означає, що право на працю є природним правом людини.

Коли людина була сама, то тільки від неї залежало питання стосовно продовження роду. Люди полювали на диких тварин, пасли худобу, збирали урожай. Рід жив та благополучно збільшувався. Якщо усі ці роботи не виконувались, то зростала ймовірність вимирання всього роду або його частини.

3 моменту виникнення держави, яка бере на себе право регулювати взаємовідносини суб'єктів всередині її території, виникло питання про реалізацію громадянами права на працю. Виникло питання про відповідальність держави перед людиною як громадянином цієї держави.

Сьогодні ми можемо говорити, що однією з найважливіших ознак правової держави й розвинутої демократії є реальне забезпечення прав людини i громадянина загалом та права на працю зокрема. Так, гарантії прав і свобод людини і громадянина є основними умовами, способами і засобами, за допомогою яких кожна особа має можливість реалізувати свої права. Як справедливо зазначав O.I. Процевський, «саме тому право на працю й умови його реалізації визначають зміст усіх норм трудового права як самостійної галузі права України, а також головний напрям в економічній політиці держави» [1].

Дослідженню питань, пов'язаних з правом людини на працю, приділяли увагу Р.З. Лівшиць,
Н.Б. Болотіна, Л.Ю. Бугров, В.В. Жернаков, O.М. Лук'янченко, В.I. Прокопенко, О.I. Процевський, В.Н. Скобелкін, В.О. Срьоменко, П.А. Бущенко, С.М.Прилипко, Г.І. Чанишева,В.В.Хромей, О.М. Ярошенко та інші вчені. Однак актуальність дослідження права на працю зумовлена тим, що, по-перше, більшість праць вказаних вчених виконувалась за часів СРСР чи відразу після переходу України на регулювання економіки у ринкових умовах праці, по-друге, необхідність дослідження права на працю у період реформаційних процесів, які відбуваються в країні після революції гідності 2014 року, є об'єктивною необхідністю. Як справедливо визначає 0.0. Коваленко, «зараз особливо гостро відчувається потреба у з'ясуванні природи, сутності права на працю, щоб розвивати та вдосконалювати трудове право в напрямі, який би грунтувався на принципах демократії, гуманізму та справедливості, проголошених головним творцем усіх матеріальних та духовних благ цивілізації працівником» $[2$, с. 40].

Метою дослідження є вирішення актуальних проблем сучасного розуміння права на працю. Для досягнення означеної мети необхідно вирішити такі завдання:

- проаналізувати чинне законодавство України з питань права на працю;

- дослідити правове регулювання права на працю у міжнародних правових актах.

Відповідно до Конституції України наша держава є правовою, незалежною, суверенною та соціальною. Найвищою соціальною цінністю в Україні є сама людина, її честь і гідність, життя і здоров'я, недоторканність. Держава несе відповідальність за свою діяльність перед людиною, визначає гарантії прав і свобод людини при здійсненні діяльності державою та ї̈ органами. Утвердження й забезпечення прав і свобод людини є головним обов'язком держави [3].

Щоб досконало досліджувати словосполучення «право на працю», нам необхідно зрозуміти, що несе у себе слово «право».

$\mathrm{y}$ «Академічному тлумачному словнику української мови» (1970-1980) слово «право» визначається як система встановлених або санкціонованих державою загальнообов'язкових правил (норм) поведінки, що виражають волю панівного класу (в експлуататорському суспільстві) або 
всього народу (в соціалістичному суспільстві); зумовлена певними обставинами підстава, здатність, можливість робити, чинити що-небудь, користуватися чим-небудь. [4]. В. Федін висловлює таке міркування: «Оскільки певному суб'єктивному праву не відповідає юридичний обов'язок, то воно трансформується у свободу" [5, с. 414]. Отже, право та свобода є нерозривно пов'язаними. Поняття «свобода» означає відсутність політичного й економічного гноблення, утиску й обмежень у суспільно-політичному житті якого-небудь класу або всього суспільства; можливість діяти без перешкод і заборон у якій-небудь галузі [6, с. 567].

«Великий енциклопедичний юридичний словник» вказує, що право - це офіційно визнані можливості, які мають громадяни та організації, а свобода - це природний стан народу або окремої людини, який характеризується можливістю діяти на власний розсуд [7, с. 667,805$]$.

Отже, право визначається у словниках як щось підтверджене, формально установлене, а свобода як те, що засноване на суб'єктивних можливостях людини. Так, Ш. Монтеск’є писав: «Свобода може бути лиш у тому, щоб мати можливість зробити те, чого можна хотіти» [8, с. 288]. На думку Дж. Локка, свобода полягає «у тому, що ми можемо робити чи не робити згідно з нашим вибором або бажанням» $[9$, с. 259$]$.

Нам необхідно розуміти, що несе в собі поняття «праця». Відповідно до «Великого енциклопедичного юридичного словника» праця - це цілеспрямована діяльність людини, що потребує фізичної або розумової енергії та орієнтована на створення матеріальних і духовних цінностей [10, с. 699].

Науковці тлумачать це поняття дещо ширше. Так, В.Ф. Пеньківський визначає: «Праця вільна, свідома, активна, творча - це основа суспільного життя. Трудова діяльність - це головна сфера життєдіяльності людини не лише тому, що праця - одна із сил природи, а й тому, що вона є головним полем діяльності та розвитку різних здібностей людини. Праця збагачує їі інтереси, зумовлює її потреби, а отже, і здобутки, власність (інтелектуальну й майнову). Тому праця - це не просто затрата людської енергії, а цілеспрямована суспільно корисна діяльність людей. У цьому полягає нерозривний зв'язок людини й суспільства, характеру праці зі способом виробництва та його результатом - власністю» [11, с. 25-26].

Ю.П. Дмитренко зазначав: «Праця - це діяльність людини, сукупність цілеспрямованих дій, що потребують фізичних i розумових затрат та мають своїм призначенням створення матеріальних і духовних цінностей. Людство розвивається завдяки праці, оскільки все, що потрібно для життя й розвитку людини, створюється працею, а її усуспільнений характер зумовлює поєднання особистих і колективних інтересів. У трудовому про- цесі людина за допомогою знарядь праці змінює предмет праці, надаючи йому відповідних властивостей, сформованих у їі уяві завчасно. Така трудова діяльність має свідомий, цілеспрямований, суспільно корисний характер, властивий усім суспільно-економічним формаціям» [12, с. 34].

На підставі вищевикладеного проаналізуємо поняття «право на працю».

У правовій науці дослідження права на працю постійно перебуває у центрі уваги. Цій темі присвячено багато наукових праць.

Так, на думку Н.Б. Болотіної, одне з основних прав людини - це право на працю. Право на працю визнане основними державами світу та закріплене у їх правових актах. Це право відповідає потребам людини своєю діяльністю здобувати для себе та членів своєї сім'ї кошти для існування [13, с. 21].

O.I. Процевський вважав, що право на працю як одне з фундаментальних прав людини відображає її об’єктивну потребу в створенні матеріальних і духовних цінностей не лише для задоволення своїх потреб, а й для існування всього суспільства та держави. Саме тому право на працю й умови його реалізації визначають зміст усіх норм трудового права як самостійної галузі права України, а також головний напрям економічної політики держави [14].

Н.С. Мокрицька висловилась, що «втіленням суттєво нового праворозуміння стала сучасна концепція прав людини, яка розглядає право на працю як природне право, що належить людині так само, як і право на життя [15].

Проаналізувавши цитовані думки вчених, можна дійти висновку, що право на працю - це одне 3 важливих соціально-економічних прав людини й громадянина, гарантоване міжнародно-правовими актами та Конституцією України, яке дає можливість кожному заробляти собі на життя працею, яку він вільно обирає або на яку вільно погоджується.

Конституція України 1996 р. у ст. 43 проголосила: «Кожен має право на працю, що включає можливість заробляти собі на життя працею, яку він вільно обирає або на яку вільно погоджується» [3]. Отже, свобода праці у Конституції України представлена як офіційно визнана можливість людини використовувати або не використовувати свої здібності до праці, а також свобода вибору саме тієї праці, яка відповідає її бажанням. Іншими словами, поняття "свобода» пов'язане з повноваженнями особистості, які окреслюють сферу ii самостійності, захист від втручання в їі внутрішній світ (свободу віросповідання, свободу думки, художньої, наукової, технічної творчості тощо).

При цьому необхідно звернути увагу на два важливих моменти. По-перше, очевидно, що як право, так і свобода мають юридичне закріплення. по-друге, тлумачення «яку він вільно обирає 
або на яку вільно погоджується» означає, що для реалізації свободи праці для громадянина не досить надання йому самостійності та відсутності заборон, від держави необхідні будь-які дії як зі створення робочих місць, так і зі створення можливості навчитися або пройти перепідготовку громадянину на ті професії, спеціальності, кваліфікації, які користуються попитом у суспільстві на даний момент.

Таким чином, коли від держави потрібно тільки утримуватися від заборон, відношення між громадянином та державою мають абсолютний і пасивний характер. Якщо для реалізації громадянином свободи з боку держави необхідні будьякі дії, то відносини, які виникли між державою і громадянином, є вже конкретно визначеними або відносними і водночас мають активний характер та виражаються у праві вимоги однієї зі сторін.

Безумовно, у сучасному суспільстві є багато проблем з реалізацією прав людини. Право на працю є однією з них. Держава повинна не лише визнати це право шляхом прийняття деяких законодавчих актів та закріплення цього права, а ще й вживати певних заходів щодо його реалізаціï. Право на працю має комплексний характер. По-перше, право на працю є економічним правом, оскільки потреби людини здобувати засоби до існування можна реалізувати лише за умови здійснення права на працю. Здійснення права на працю полягає в адекватності оплати праці трудовим затратам з одного боку, а з другого - оплата праці повинна забезпечувати людині гідне існування. По-друге, право на працю є також соціальним правом людини. Соціальність (походить з франц. мови) означає громадськість, таке, що характеризує спільне життя, взаємні обов'язки цивільного побуту. Соціальність (від лат. «спільний, громадський») - це назва усього міжлюдського, тобто пов'язаного зі спільним життям людей, з різними формами їх спілкування, зокрема і суспільства та громади, що має міжособистісний i суспільний характер. Таким чином, соціальність права на працю виявляється у тому, що держава встановлює коло соціальних стандартів і державних гарантій у сфері праці, які мають бути дотримані будь-яким роботодавцем i не можуть бути зменшені. Соціальність закріплює обов'язок роботодавця своїми внесками брати участь у соціальному страхуванні працівника на випадок його непрацездатності, безробіття, трудового каліцтва, професійного захворювання, старості тощо. Вона зобов'язує роботодавця виділяти частину прибутку від одержаних доходів і направляти їх на соціальний розвиток працівників - на охорону праці, поліпшення соціальних умов праці, забезпечення соціально-побутових умов, заходів з охорони здоров'я. Соціальність забезпечує можливість особи отримати від держави допомогу в працевлашту- ванні, а також забезпечити рівень життя, гідний людини, для себе та членів своєї сім'ї. Також на вимогу законодавця роботодавець бере участь у соціальному страхуванні працівника, повинен спрямовувати гроші на охорону праці, забезпечувати необхідні заходи з охорони здоров'я тощо.

Визначальними у забезпеченні права на працю є свобода праці й заборона примусової праці. Принцип свободи праці закріплений у конституціях держав, які проголосили себе соціальними.

Закріплення права громадян на працю в конституціях європейських держав було реалізоване після закінчення Другої світової війни [16, с. 34]. Це було зумовлено тим, що в Конституції однієї 3 держав-переможниць у Другій світовій війні Радянському Союзі - це право було введене в ранг конституційного задовго до війни, а авторитет Радянського Союзу наприкінці війни був досить високим. У країнах Європи ліві та лівоцентристські партії боролися за місце в парламентах своїх держав, вимагали прийняття програм соціальної трансформації та їх законодавчого закріплення.

Аналізуючи конституції зарубіжних держав, ми виділили кілька підходів до розуміння категорії права на працю.

Перший підxід. Право на працю не закріплюється в конституції, оскільки з урахуванням національних особливостей окремих держав право на працю є складовою частиною права займатися економічною діяльністю (США, Японія) [17, с. 156].

Другий піәхід. Під правом на працю мається на увазі право кожного вільно здійснювати будь-яку працю, заняття відповідно до отриманої освіти, досвіду і професійної кваліфікації. Це характерно для Угорщини, Албанії, Хорватії, Мексики та ін. $[17$, с. $160 ; 18$, с. 56$]$.

Третіŭ підхід. Право на працю розуміється як право на одержання гарантованої роботи. Нині таке трактування права на працю не є актуальним, оскільки гарантоване право на працю обтяжене обов' язком громадянина працювати, щоб не настали встановлені в певних країнах негативні наслідки (КНДР, Китай) [17, с. 158].

Четвертий підхід. Право на працю є одночасно і обов'язком громадянина працювати. Але цей обов'язок морально-етичного характеру, тобто у разі його невиконання не настає якась юридична відповідальність (Італія, Іспанія, Греція). Право на працю в цих країнах виступає принципом конституційного ладу. Наприклад, у ст. 4 Конституції Італії від 22 грудня 1947 р проголошено, що республіка визнає за всіма громадянами право на працю і створює умови, які роблять це право реальним. Однак у другій частині цієї статті проголошено, що кожен громадянин відповідно до своїх можливостей і за своїм вибором зобов'язаний здійснювати діяльність або виконувати функції, що сприяють матеріальному або духовному роз- 
витку суспільства [19]. Ні в Конституції Італії, ні в інших законних і підзаконних нормативних актах відповідальності за невиконання цього обов'язку не передбачено. У ст. 35 Конституції Іспанії від 29 грудня 1978 р. також проголошено, що всі іспанці зобов' язані працювати і мають право на працю [21].

У сучасному світі є різні правові концепції розгляду права людини на працю.

Перша концепція поширена в багатьох промислово розвинених державах, в тому числі в США і Японії, та, мабуть, є найбільш ліберальною з них усіх. Ця концепція грунтується на запереченні самостійності трудового права як галузі права. Держава в окремих законах проголошує певні соціальні гарантії, встановлює заборону примусової праці і не втручається в соціальні відносини.

Друга і третя концепції близькі між собою, але між ними є і деякі суттєві відмінності. Згідно з другою концепцією право на працю - це «голе» право, фактично позбавлене будь-яких соціальних гарантій. Право на працю фактично зводиться до заборони на примусову працю. Третя концепція пов'язана з активною участю держави у вирішенні соціальних проблем населення. Однак і в тому, $\mathrm{i}$ в іншому випадку громадянин позбавлений права звернутися до держави і зажадати надання йому гарантованого робочого місця.

Четверта концепція, здавалося б, надає право на працю громадянину. У соціалістичних державах нерідко воно реалізовувалося системою розподілу випускників навчальних закладів. Неважко помітити, що при цьому порушувався принцип свободи праці. Так, введення системи розподілу у Франції пару років тому призвело до студентських заворушень. Французькі студенти порахували, що для них краще залишитися безробітними після закінчення вузу і отримувати допомогу, ніж поїхати працювати фактично на кабальних умовах за багато кілометрів від рідного дому. Дійсно, втрутившись в процес найму на роботу, держава змусила роботодавців знизити заробітну плату в декілька разів для колишніх студентів, що призвело до порушення такого права людини, як право на справедливі умови праці, і принципу справедливості в трудовому праві взагалі (принципу рівної оплати за рівну працю).

Отже, право на працю не є суб'єктивним правом людини. Держава повинна створювати робочі місця для своїх громадян, організовувати можливість працівникам перенавчатися на інші спеціальності, професії, але громадянин не має права вимагати від держави надання йому праці. Саме цей підхід до права на працю людини ми бачимо в багатьох державах Європи. Загалом можна визнати, що цей підхід сприйнятий і в Україні.

Зрозуміло, що відповідь на питання, чим $\epsilon$ право на працю, пов'язана з тими чи іншими ідеологічними переконаннями. Однак, вважаємо, що третя концепція є більш обгрунтованою, хоча навряд право на працю може виступати як моральний обов'язок. Ідея моральних обов'язків позбавлена юридичного сенсу і $є$ нонсенсом з точки зору професійного юриста, переконаного, що немає прав без відповідних обов'язків. Якщо за невиконання обов'язків не виникає права залучити порушника до юридичної відповідальності, то це не обов'язок. Можливо, праця є певним моральним обов'язком кожної людини, однак чи є необхідним про це нагадувати в конституції? Для цього є сім'я і школа.

Отже, ми можемо констатувати, що право на працю є комплексною правомочністю громадянина. Воно включає в себе низку інших прав, зокрема право на свободу праці, право на безпечні умови праці, право на рівні умови праці тощо. Більшість перерахованих прав є відносними і адресованими державі, яка зобов' язана контролювати всі сфери діяльності для їх дотримання і виконання.

Аналізуючи ст. 8 Міжнародного пакту про громадянські і політичні права 1966 року, ми дійшли висновку, що примус до праці є порушенням основних прав людини [21, ст. 8]. Свобода праці - це абсолютне право, воно стосується невизначеного кола осіб, як і право власності, право на життя i інші конституційні права людини і громадянина. Як абсолютне право це право має пріоритетне значення серед інших прав, які становлять зміст комплексного права на працю. Свобода праці є одним з основних прав людини, невід'ємних і невідчужуваних за своєю природою, як і свобода слова, свобода думки, свобода пересування тощо. Людина, позбавлена свободи праці, перетворюється на раба, фактично втрачає людську гідність. Іншими словами, сутність людини з погляду забезпечення iï матеріального існування полягає в її здатності працювати. 3 погляду соціального розвитку людини право на працю - це її свобода.

\section{Jimepamypa}

1. Процевський O.I. Новий зміст права на працю основа реформування трудового законодавства України. Право України. 1999. № 6. С. 101-105.

2. Коваленко 0.0. Актуальні проблеми сучасного розуміння права на працю. Університетські наукові записки. 2016. № 59. С. 39-51.

3. Конституція України : Закон України від 28 червня 1996 р. № 254к/96-ВР / Верховна Рада України. Вiдомості Верховної Ради Украӥни. 1996. № 30. Ст. 141.

4. Академічний тлумачний словник української мови. URL: http://sum.in.ua/s/pravo.

5. Федин В.В. Соотношение принципа свободы труда и права на труд. Lex Russica. 2004. № 2. C. 411-436.

6. Академічний тлумачний словник української мови. URL: http://sum.in.ua/s/pravo.

7. Великий енциклопедичний юридичний словник. Київ : Видавництво «Юридична думка», 2007. C. 667,805 .

8. Монтескье Ш. Избранные произведения. Москва, 1955. С. 288-289. 
9. Локк Дж. Избранные философские произведения : В 2 томах. Москва, 1960. Т. 1. С. 259.

10. Великий енциклопедичний юридичний словник / за редакцією ак. НАН України Ю.С. Шемшученка. Київ : Видавництво «Юридична думка», 2007.990 c.

11. Право на працю та інші соціально-економічні права людини і громадянина / В.Ф. Пеньківський, Л.С. Нецька, О.В. Тищенко. Київ : ВГЛ «Обрії, 2012. 306 c.

12. Дмитренко Ю.П. Трудове право України. Київ : Юрінком Інтер, 2009. $624 \mathrm{c.}$

13. Болотіна Н.Б. Трудове право України. Київ : Знання, 2008. $860 \mathrm{c.}$

14. Процевський O.I. Чи дійсно держава не гарантує громадянам право на працю? Збірник наукових праць Харківського національного педагогічного уні верситету імені Г. С. Сковороди. Серія «ПРАВО». 2013. № 20. С. 10-18.

15. Мокрицька Н.С. Про сутність проголошеного у Конституції України права на працю. URL: http://vuzlib.com/content/view/2451/115/.

16. Конституционное право зарубежных стран / отв. ред. В.В. Чиркин. Москва, 1997.

17. Конституционное (государственное) право зарубежных стран. Часть общая: конституционное (государственное) право и его основные институты / отв. ред. Б.А. Страшун. Москва, 2000. Т. 1-2.

18. Конституции государств Центральной и Восточной Европы / отв. ред. Н.В. Варламова. Москва, 1997.

19. Конституція Італії від 22 грудня $1947 \mathrm{p}$. URL: https://worldconstitutions.ru/?p=148.

20. Конституція Іспанії від 29 грудня 1978 р. URL: https://worldconstitutions.ru/?p=149.

21. Міжнародний пакт про громадянські і політичні права 1966 року. URL: https://zakon.rada.gov.ua/ laws/show/995_043.

\section{Анотація}

Китайгородська В. В. Поняття та зміст права людини на працю. - Стаття.

3 моменту виникнення держави, яка бере на себе право регулювати взаємовідносини суб'єктів всередині iї території, виникло питання про реалізацію громадянами права на працю. Виникло питання про відповідальність держави перед людиною як громадянином цієї держави.

У даній статті було розглянуте питання стосовно того, що однією 3 найважливіших ознак правової держави, розвинутої демократії є реальне забезпечення прав людини і громадянина загалом та права на працю зокрема. Також були досліджені гарантії прав і свобод людини і громадянина, які є основними умовами, способами i засобами, за допомогою яких кожна особа має можливість реалізувати свої права.

Проаналізовано чинне законодавство України з питань права на працю. Досліджено правове регулювання права на працю у міжнародних правових актах. Проаналізовано наукові праці вчених та зроблено висновок, що право на працю - це одне з важливих соціально-економічних прав людини й громадянина, гарантоване міжнародно-правовими актами та Конституцією України, яке дає можливість кожному заробляти собі на життя працею, яку він вільно обирає або на яку вільно погоджується. Зроблено висновок про те, що право на працю не є суб'єктивним правом людини. Автор стверджує, що держава повинна створювати робочі місця для своїх громадян, організовувати можливість працівникам перенавчатися на інші спеціальності, професії, але громадянин не має права вимагати від держави надання йому праці. Саме цей підхід до права на працю людини ми бачимо в багатьох державах Європи.

Зроблено висновок про те, що право на працю $\epsilon$ комплексною правомочністю громадянина. Воно включає в себе низку інших прав, зокрема право на свободу праці, право на безпечні умови праці, право на рівні умови праці тощо.

Ключові слова: право людини, право на працю, гарантії, права і свободи громадянина, життя.

\section{Summary}

Kytaihorodska $V$. $V$. The concept and content of the human right to work. - Article.

Since the emergence of a state that assumes the right to regulate the relations of subjects within its territory, the question arises about the citizens' realization of the right to work. The question arises about the responsibility of the state to the person, citizen of this state.

This article addresses the issue of one of the most important features of a rule of law, a developed democracy, is the real protection of human and citizen rights in general and the right to work in particular. Guarantees of human and citizen's rights and freedoms have also been investigated, and as a general concept, they are first and foremost the basic conditions, ways and means by which each person is able to exercise his or her rights.

The author analyzed the current legislation on the right to work in Ukraine; legal regulation of the right to work in international legal acts is investigated. The scientific works of scientists were analyzed and it was concluded that the right to work is one of the important socio-economic rights of the citizen and citizen, guaranteed by international legal actions and the Constitution of Ukraine, which gives the power to which one agrees. It is concluded that the right to work is not a subjective human right. The author states that the state should create jobs for its citizens, organize the opportunity for workers to study in other specialties, professions, but the citizen does not have the right to require the state to provide him with work. It is this approach to the right to work for human beings that we see in many countries in Europe.

The author concludes that the right to work is a comprehensive competence of a citizen, which includes a number of other rights - the right to freedom of work, the right to safe working conditions, the right to equal working conditions, etc.

Key words: human right, right to work, guarantees, rights and freedoms of a citizen, life. 